\title{
Demonstration projects in transition processes to sustainable energy and transport
}

\author{
Antje Klitkou \\ Department for Studies in Research and Innovation, \\ NIFU Nordic Institute for Studies in Innovation, \\ Research and Education, \\ P.O. Box 2815, Tøyen, \\ Oslo 0608, Norway \\ Email: antje.klitkou@nifu.no
}

\begin{abstract}
In this paper, an analysis was made of the role of public support schemes funding demonstration, test and trial activities for sustainable development in energy and road transport. This paper presents the analysis of the effects of demonstration projects in transition processes to sustainable energy and transport in the Scandinavian countries on the development of knowledge networks and on interaction with users. The main purpose of this paper is: (1) to analyse the role of publically funded demonstration projects concerning changes in knowledge networks of project participants over time; (2) analysing policy priorities in collaboration by the public funding programmes. The paper addresses following research questions: (1) How successful are Scandinavian demonstration projects in contributing to the development of knowledge networks for sustainable energy and transport transitions? (2) Do Scandinavian demonstration programmes prioritise learning in international knowledge networks and user involvement? (3) How have demonstration projects contributed to transition processes?
\end{abstract}

Keywords: demonstration projects; networking; social network analysis; sustainable energy; sustainable transport; transition processes.

Reference to this paper should be made as follows: Klitkou, A. (2016) 'Demonstration projects in transition processes to sustainable energy and transport', Int. J. Foresight and Innovation Policy, Vol. 11, Nos. 1/2/3, pp. $96-125$.

Biographical note: Dr. Antje Klitkou obtained her PhD from Humboldt University, Berlin. Since 2002, she has worked at NIFU as a Senior Researcher, and since 2004 as a Research Professor. She has research interests in research and innovation policy in general, and especially in the energy and transport sector. She has been responsible for several projects. She combines quantitative and qualitative research methods. She has authored several articles on innovation networks, science-industry collaboration, scientific and industrial specialisation, research and innovation policy and renewable energy. The most recent of her research projects was 'Technology Opportunities in Nordic Energy System Transitions' (2011-2015), funded by Nordic Energy Research and based on Nordic cooperation. The Scandinavian project 'Role of demonstration projects in innovation: transition to sustainable energy and transport' (RCN, 2013-2014) combined among others social network analysis and policy analysis. 
This paper is a revised and expanded version of a paper entitled 'Demonstration projects in transition processes to sustainable energy and transport', presented at June 18th, 2014, EU-SPRI 2014 Conference, Manchester.

\section{Introduction}

In the transition towards sustainable energy and transport systems, the development and up-scaling of niche experiments play a decisive role. The problems of the incumbent fossil-based socio-technical regime increase possibilities for niche development, but this is not sufficient to succeed. Public support for niche development is required. This paper analyses the role of public support schemes funding demonstration, test and trial activities for sustainable development in energy and road transport. As empirical material, the paper analyses such public support schemes in Scandinavian countries Denmark, Norway, and Sweden.

Demonstration projects target core processes and key instruments needed to facilitate the alignment of promising new technologies with societal conditions. Such alignment is necessary for the successful adoption of radical new technology and whether the development and diffusion of emergent technologies in the transition to more sustainable energy and transport systems is to be sustained and accelerated. Demonstration projects have proven to be an important instrument for policy-makers, researchers and firms in helping to reduce uncertainty and to facilitate learning about the acceptance, desirability and adaptation of new technology in society. Interaction with societal actors, monitoring experiences with governance of such projects and policy learning are important issues.

National funding programmes for demonstration and trial projects for sustainable energy and transport solutions have to balance two priorities:

1 By addressing so-called 'Grand Challenges' supporting the transition towards more sustainable solutions.

2 By improving funding possibilities for demonstrating and testing new solutions strengthening the competitiveness of national actors.

While transition processes require international collaboration, the national policy focus often excludes international knowledge exchange. Such tensions have to be addressed (Kallerud et al., 2013, p.18). Another interesting question is also if demonstration projects are based on collaboration between the usual suspects, such as firms and R\&D organisations, or if they include as well other types of societal actors, such as NGOs, local authorities or private foundations (Kallerud et al., 2013, p.18f.).

The project selected technologies that are promising platforms for a transition to a more sustainable energy and transport system such as renewable electricity, hydrogen, and sustainable biofuels. The future development pathways of these technologies are challenged by a high degree of technological, social and economic uncertainty as well as durability of the incumbent fossil-fuel-based energy and transport systems.

The measurement of outcomes, effects and long-term impacts of trial and demonstration projects can provide important insights for policy-makers. Countries have invested heavily in trial and demonstration projects for sustainable energy solutions over recent years. This makes it crucial to understand why certain projects do or do not 
succeed, and how the funding programmes can be improved. Success can be measured by comparing the aims of the projects and the achieved outcomes. Intangible learning outcomes (Kamp, Smits and Andriesse, 2004) and strengthened networking between firms, technology providers, authorities, user groups and other stakeholders are important (Hoogma et al., 2002).

The following processes have been highlighted in the transition literature as decisive for successful niche development: facilitating learning processes, the formation of broad and aligned networks and institutional embedding, voicing and shaping of expectations and visions, and the development of complementary technologies and infrastructures (Hoogma et al., 2002, p.30; Raven, 2005). This paper concentrates particularly on the formation of broad and aligned networks and involvement of users, both industrial and customers. This paper gives the results of the analysis of the effects of demonstration projects in transition processes to sustainable energy and transport in the Scandinavian countries on knowledge networks with different types of actors.

The main purpose of this paper is twofold:

1 To analyse the role of public funded demonstration projects for the changes of the knowledge networks of project participants over time.

2 To provide an analysis of policy priorities for collaboration by the public funding programmes.

Accordingly, following research questions have been pursued:

1 How successful are Scandinavian demonstration projects in their contribution to the development of knowledge networks for sustainable energy and transport transitions?

2 Do Scandinavian demonstration programmes prioritise learning in international knowledge networks and user involvement?

3 How have demonstration projects contributed to transition processes?

The paper is structured as follows. Following the introduction, the theoretical background for the paper is discussed. Then, the data and applied methods of analysis are explained. The results section is divided into two parts: a presentation of the social network analysis (SNA) of collaboration patterns in the demonstration projects and a comparative analysis of the policy priorities of the funding programmes. Finally, follow policy conclusions.

\section{Theoretical background}

To answer the research questions, this paper draws upon knowledge from three strands of literature:

1 Strategic niche management

2 National innovation systems

3 Governance of transition processes. 


\subsection{Strategic niche management and demonstration projects}

The strategic niche management approach has been developed to address niche processes and, to some degree, to provide policy-makers with a tool for supporting niche development (Hoogma et al., 2002, p.29). Kemp, Schot and Hoogma (1998, p.186) define strategic niche management as 'the creation, development and controlled phase-out of protected spaces for the development and use of promising technologies by means of experimentation, with the aim of

1 learning about the desirability of the new technology

2 enhancing the further development and the rate of application of the new technology.

Policy interventions in socio-technical systems are not only relevant for the selection of niche technologies through experimentation (Klitkou et al., 2013, p.14); policy interventions also include 'the articulation of expectations and visions, network formation, resource allocation, favouring open-ended learning processes, and supporting technology diffusion (up-scaling)' (Coenen and Díaz Lopez, 2010, p.1156).

Hoogma (2000, p.67) distinguishes between four types of experiment relevant for creating niches:

1 Explorative experiments at early stages of learning to help define problems, explore user preferences and possibilities for changing the innovation, and to learn how future experiments should be set up.

2 Pilot experiments to raise public and industrial awareness, stimulate debate and open policy-making, test the applicability of innovations in locations with similar conditions, or to test the feasibility and acceptability of innovations in new environments.

3 Demonstration experiments to 'show potential adopters how they may benefit from the innovations. They may either be the follow-up of explorative or pilot experiments, or be designed specifically to promote the adoption of an innovation' (Raven, 2005, p.38).

4 Replication or dissemination experiments to disseminate tested methods, techniques or models through replication which involves full-scale implementation of a technology (Klitkou et al., 2013, p.15).

Raven emphasises that experiments and niches are not the same. In niches the 'local experiments and practices are compared, lessons and expectations are transferred between locations, and delocalised general knowledge of the technology in question is formulated' (Raven, 2005, p.38). He also emphasises that experiments reflect three main evolutionary and sociological aspects of niches.

- Experiments bridge the gap between variation and selection environments: 'Interaction between technology actors (firms, research institutes), societal actors (users, environmental groups), and regulating actors (public authorities) may contribute to integrating the concerns of different groups into the design' (Raven, 2005, p.38). 
- Experiments are protected from some of the rules that make up the dominant sociotechnical regime: public authorities give subsidies for lowering risks for involved firms and firms may decide to test the feasibility of a technology in a pilot plant because of strategic decisions.

- Experiments are often characterised by limited structuration and high uncertainty, especially in early stages of experimentation (Klitkou et al., 2013, p.15).

An example of the differences between experiments and niches in a Norwegian transportation context is the introduction of the worldwide first electric ferry in Hordaland county in 2014 as a new experiment with sustainable transport solutions, and the deployment of and broad policy support for battery-driven vehicles as a market niche.

Instability of the socio-technical regime increases opportunities for niche development, which can result in increased niche size. Raven distinguishes between three possible avenues of niche development:

1 Regime instability can create local opportunities for experiments and niche actors develop expectations linked to regime instability.

2 With a decreasing stability of the regime, actors become interested in the niche because of promising options for the future.

3 In the case of very high instability of the regime a niche can be adopted by the regime as a problem-solver, but for this a sense of urgency has to become prominent in political visions and agreements (Raven, 2005, p.260).

However, the instability of the regime is not sufficient for niches to succeed. The quality of niche processes is decisive. The following processes have been highlighted in the literature as decisive for successful niche development: facilitating learning processes, the formation of broad and aligned networks and institutional embedding, parallel application of technologies in different geographical locations, voicing and shaping of expectations and visions, and the development of complementary technologies and infrastructures (Coenen, Benneworth and Truffer, 2012; Hoogma et al., 2002, p.30; Raven, 2005).

Hoogma et al. highlight the following aspects of learning as relevant for niches:

1 Design specifications of technical development and infrastructure.

2 Development of the user context including user characteristics, their demands and their barriers to use the new technology.

3 The societal, safety and environmental impact of the new technology.

4 Required industrial development including production and maintenance networks to facilitate diffusion of the new technology.

5 Government role and regulatory framework in the introduction process and possible incentives to stimulate adoption (Hoogma et al., 2002, p.28).

Hoogma et al. identify three aspects of institutional embedding in niche development:

1 Embedding including the development of complementary technologies and the necessary infrastructure. 
2 Institutional embedding which produces widely-shared, specific and credible expectations and which are supported by facts and demonstration successes.

3 Embedding which ensures inclusion of a broad array of actors aligned in support of the new technology - aligned network of producers, users, third parties, especially government agencies (Hoogma et al., 2002, p.29).

Coenen et al. emphasise the need for analysing institutional embedding in the geographical context for explaining 'the extent to which and in what ways geographically uneven transition processes are shaped and mediated by institutional structures' (Coenen, Benneworth and Truffer, 2012, p.973).

Raven emphasises that broad social networks include producers, users, regulators, societal groups, and that these networks carry expectations and articulate new demands and requirements (Raven, 2005). There are two characteristics of networks, which are important for niche development:

1 The composition of the network.

2 The alignment of actors' activities (Raven, 2005, p.40f.).

Regarding the composition of the network, actors have to be included who are willing to invest in maintaining or expanding the niche. These may be large established firms, which support the incumbent technology regime, and there is therefore a risk for inertia and path extension. A dominance of established firms can lead to dominance of incremental innovations. The network should also involve actors who have no strong ties with the existing regime, but these often have limited resource mobilisation potential and may not be able to maintain the niche over a long time. The active involvement of users, both industrial and customers, is important but also the involvement of non-user groups, which are affected by the impact of the technology (neighbouring residents, environmental groups, and concerned citizens) (Verheul and Vergragt, 1995). Raven points out that traditionally SNM literature has a focus on users for generating secondorder learning processes, but he emphasises that involvement of non-industrial users is not always particularly relevant for industrial niche projects. Here, it might be more relevant to involve environmental organisations or concerned citizens representing, for instance, the neighbours of an experiment. 'Including these groups at an early phase of experimentation can result in the inclusion of their concerns in the innovation process and prevent societal resistance in later phases through early adjustment of the design' (Raven, 2005, p.257). There is also a possibility for these actors to participate in the experiments, taking part in the organisation of the plant.

The alignment of actors' activities refers to 'the degree to which actors' strategies, expectations, beliefs, practices, visions, and so on go in the same direction, run parallel' (Raven, 2005, p.40). Rip understands alignment as a concept 'that indicates the mutual and well-functioning adjustment' of strategies and visions at the network level (Rip, 1995, p.424). Visions may differ significantly between established firms and new firms, and the alignment in a network requires special effort. Rip points out the importance of macro-actors such as large technology introducers, government agencies and other 'general interest' actors, as well as relatively independent, and specially constructed macro-actors like 'platforms' or mixed consortia (Rip, 1995, p.426). 


\subsection{Innovation systems}

An innovation system encompasses elements and relationships, which interact over time in the production, diffusion and use of new and economically useful knowledge. Lundvall defines 'a system of innovation [as being] constituted by elements and relationships which interact in the production, diffusion and use of new, and economically useful, knowledge and that a national system encompasses elements and relationships, either located within or rooted inside the borders of a nation state' (Lundvall, 1992a, p.2). Structural elements of innovation systems are knowledge, actors and networks, which evolve over time. The role of different types of actors such as firms, public authorities, research organisations, and trans-national organisations and their interaction are central to an innovation system. There are different approaches to the study of innovation systems, defined by the delineation of the system:

- National innovation systems (NIS) focussing on an innovation system defined by the national borders (Freeman, 2002; Lundvall, 1992b; Nelson, 1993).

- Regional innovation systems (RIS) defined by the region in focus - either part of a nation state or crossing borders (Asheim and Gertler, 2005; Cooke, 2001).

- Sectoral innovation systems defined by the industry in focus (Malerba, 2004).

- Technological innovation systems (TIS) defined by the technology in focus (Bergek, Hekkert and Jacobsson, 2008; Carlsson and Stànkiewicz, 1991).

- Corporate innovation systems (CIS) defined by the innovative performance of a corporation or a group of collaborating companies (Granstrand, 2006).

Innovation systems may traverse industrial and geographical borders: TIS and RIS might involve several industrial sectors and traverses national borders. NIS also involves transnational organisation and knowledge made available through international networks. Intellectual property rights as a governance mechanism includes coordination aspects and incentives to disclosure and diffusion of new inventions to foster innovation systems (Granstrand, 2005, 2006).

Transition processes require changes in the NIS. Here, we are especially interested in the relationships between the elements of NIS, and more specifically networking - a process by which different types of knowledge are transferred through collaboration, cooperation and long-term network arrangements (OECD, 2002, p.15). Companies can be analysed according to size (small and medium-sized, large), status (new entrants or incumbent), and special characteristics (domestic or foreign). How does the innovation literature reflect the existing innovation networks in the Scandinavian countries? Here, the comparative study of the innovation systems in 10 small countries was used as a point of departure. The paper revisited their assessment of the state of affairs regarding networking in the three countries based on community innovation survey (CIS) data and a general assessment of the countries (Edquist and Hommen, 2008), combining them with other relevant literature on the three countries. 


\subsubsection{Denmark}

In Denmark, "the "mode of innovation" [is] dominated by small and medium-sized enterprises (SMEs) continuously making incremental innovations based on learning by doing, learning by using and learning by interacting, especially with customers and suppliers' (Christensen et al., 2008, pp.403, 404). Established trust relations are easing the exchange of information.

Some attempts have been made to use specific survey data for the Danish energy innovation system (Borup et al., 2009; Borup et al., 2008; Borup, Jacobsen and Bagratunjan, 2013; Tanner et al., 2009). The most recent report shows that a large share of cooperation relations is interaction in Denmark, while only a smaller share is international collaboration (Borup, Jacobsen and Bagratunjan, 2013).

\subsubsection{Norway}

Collaboration between firms is important for the NIS of Norway (Grønning, Moen and Olsen, 2008). The most frequent partners are suppliers followed by customers and research institutes. About a third of the firms had Scandinavian or European partners. Firms that collaborated with US partners were mainly 'large firms with activities related to oil and gas, shipping and production of chemicals. Smaller firms within other sectors such as aquaculture and furniture did not report any such collaboration' (Grønning, Moen and Olsen, 2008).

The strong position of the research institutes has functioned as a buffer for the system, but has also functioned as a lock-in mechanism which functions as 'a disincentive to firms developing competitive in-house or firm-to-firm collaborative R\&D activities' (Grønning, Moen and Olsen, 2008, p.310).

\subsubsection{Sweden}

According to Bitard et al. (2008), the underlying challenge of the Swedish innovation system is the dominance of large incumbent firms and the limited expenditures of SMEs on innovation. While there is a strong development in the knowledge-intensive business services also regarding networking, the innovativeness of the engineering and manufacturing sectors is less developed. Performance was poorer for process innovations than for new (to the firm) product innovations. Bitard et al. highlight also a mismatch between specialisation in R\&D and technology 'potentially explaining that there is a problem in transferring scientific knowledge into industrial needs in Sweden' (Bitard et al., 2008, p.245). Based on an analysis of CIS data, they conclude that the proportion of cooperating enterprises was quite low compared to other European countries.

\subsection{Transition management: governance of transition processes and policy priorities}

Transition to more sustainability requires not just niche-related activities, but also purposeful changes in the governance to transform the dominating socio-technical regime (Smith, Voss and Grin, 2010).

The governance of the transformation of socio-technical regimes has to address 
1 the articulation of selection pressures on the dominant regime

2 the coordination of available resources inside and outside the incumbent regime to adapt to these pressures (Smith, Stirling and Berkhout, 2005).

Different actors in society such as firms, non-governmental organisations (NGOs), political parties, and public authorities. Develop their visions and strategies in response to selection pressures. These articulations can differ regarding coherence and directionality, and the extent to which they are knowledge-based. The actors inside the incumbent regime will mobilise their capacities to adapt to the articulated pressures. In the case where the adaptive capacity of the incumbent regime is not sufficient, actors outside the regime such as in external niches have to be involved and challenge the regime. Such transformation processes require negotiation, bargaining for resources and priorities as well as coordination of actions between interested public and private actors.

According to the transition management literature, changes arise through the interaction between the following levels of governance activities: strategic, tactical and operational, and reflexive (Kemp, Loorbach and Rotmans, 2007, p.82; Loorbach, 2007, p.101ff.). Loorbach and Rotmans (2010) explain these levels of governance activities:

1 Strategic level: processes of vision development, strategic discussions, long-term goal formulation, culture change etc. This includes governance activities related to long-term changes, which are not institutionalised in regular political cycles and have a time horizon of $30-50$ years.

2 Tactical level: processes of agenda-building, negotiating, networking, coalition building, identification of 'barriers' etc. This includes steering actions (planning and control, prioritisation of financial support and programmes) and institutions (rules, regulations, organisations, networks, routines, infrastructure) related to the dominant socio-technical regime and have a time horizon of 5-15 years.

3 Operational level: processes of experimenting, project building, implementation of governance, and autonomous actions to achieve individual goals, etc. This is the level of radical innovation, referring to activities with a time horizon of up to 5 years.

4 Reflexive: cross-cutting processes of monitoring, assessment and evaluation of policies and processes, by a wide variety of organisations and citizens, for different purposes.

To analyse policy priorities includes, therefore, not only just the priorities of the demonstration programmes, but also the underlying visions and long-term goals in the respective society at the strategic level, for example visions for a fossil-free society and the process of agenda-building at the tactical level, for example which has been involved in the prioritisation process and what kind of routines and regulations have been established to realise the identified priorities. At the operational level, the different experiments have to be governed and which is relevant both for the demonstration programmes and for the projects. Our literature review revealed the following conclusions regarding the governance of demonstration projects and programmes (Klitkou et al., 2013):

- User involvement is crucial at all stages of demonstration projects to facilitate information and learning. 
- Project design should not be rigid to allow user input and modifications to improve effectiveness.

- Careful planning to take account of market readiness and user participation.

- Consideration of the optimal size of the projects.

- Dissemination of results and evaluation information should be included in the project design.

- Projects should ensure in their budgets performance monitoring, maintenance and trouble-shooting, which are all essential for learning.

- The programme should be clear about the maturity of the technology to be demonstrated. Subsidies for demonstration projects and trials of new generations of technology should not be used for the older generation of technology (Klitkou et al., 2013, Table 1).

Table 1 Summary of theoretical framework
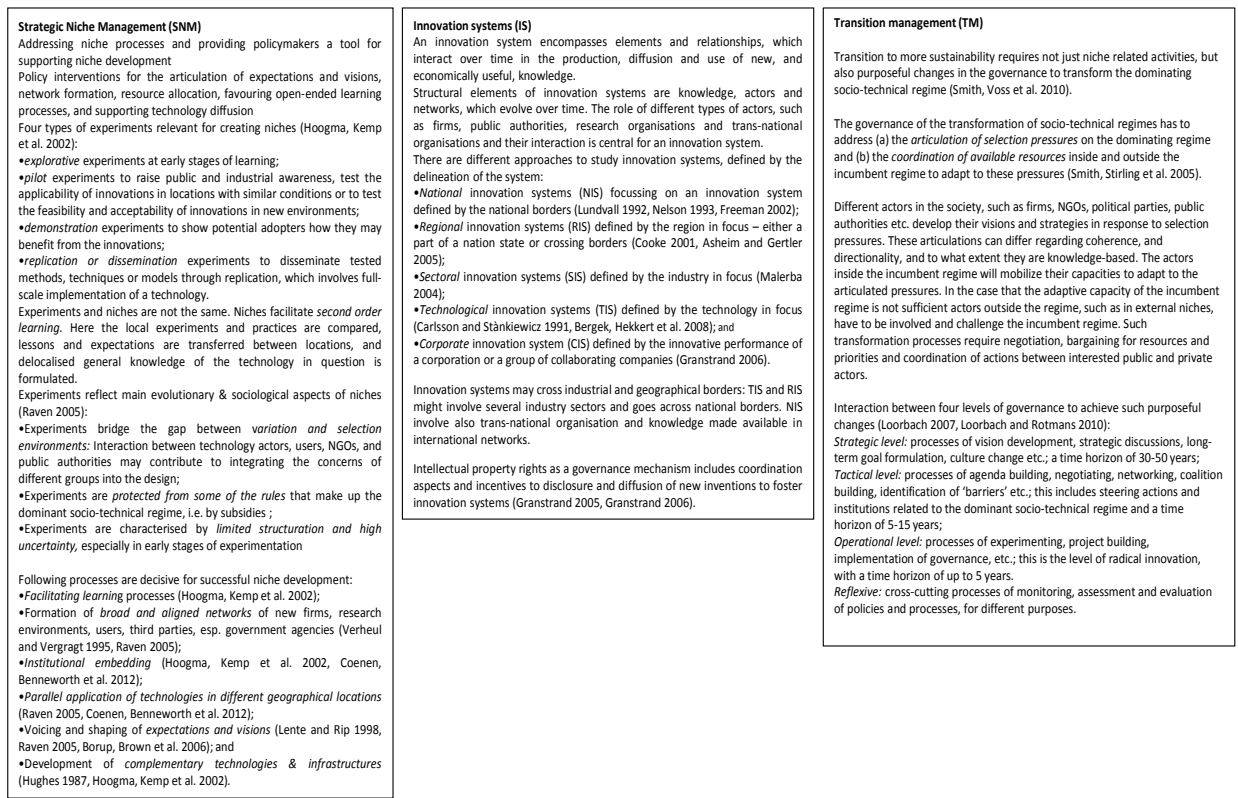

\subsection{Data and methods}

This paper is based on the results of the comparative database over demonstration and trial projects funded by public agencies or programmes in Scandinavia covering the period 2002-2012. The database contains information about the targeted energy and transport technologies, project aims, project partners, funding programmes, duration, and funding (Dannemand Andersen et al., 2014).

First, some of the basic results of the analysis of the data regarding the number of projects and project aims are presented. Then follows an explanation of the methodology and data source for answering the research questions. 
There were 433 demonstration projects commencing in the period 2002-2012 (Figure 1), of which 224 projects were in Denmark, 107 projects in Norway 107, and 102 projects in Sweden (Dannemand Andersen et al., 2014). Less than a quarter of all projects targeted road transport solutions, mainly electric mobility and biofuel/biogas. The projects received public grants of more than $€ 455$ million.

Figure 1 Number of projects in the database; distributed over starting years and countries. $N=433$

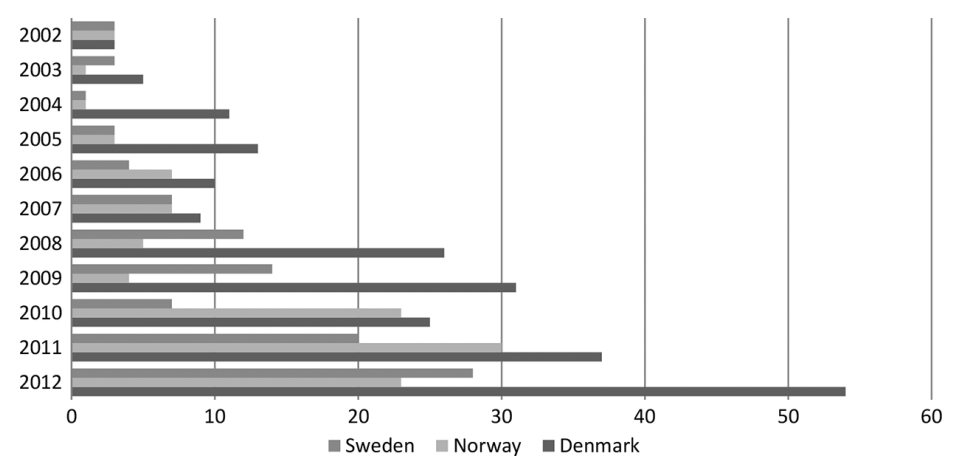

The taxonomy of demonstration project aims developed by the group around Harborne, Hendry and Brown (Harborne and Hendry, 2009; Hendry, Harborne and Brown, 2010) was further developed, and distinguished between following aims (Klitkou et al., 2013, p.22f.), acknowledging that projects can have several aims, and categorised the identified projects accordingly:

- To prove technical feasibility

- To reduce building, operating and maintenance costs

- To prove feasibility in commercial applications

- To prove environmental feasibility

- To contribute to the formation of knowledge networks

- To improve public acceptance

- To introduce institutional embedding

- $\quad$ To expose system weaknesses

- $\quad$ To facilitate learning (Dannemand Andersen et al., 2014).

From the analysis of the database, it was concluded that proving technical feasibility was the aim in more than half of the projects (Figure 2), while for one-third of the projects the following aims were: to reduce building, operating and maintenance costs, to prove feasibility in commercial applications, and to facilitate learning. In less than a quarter of the projects, the aim was to contribute to the formation of knowledge networks. The other aims were less prominent. 
Figure 2 Number of projects with specific aims for each country, each project can have multiple aims

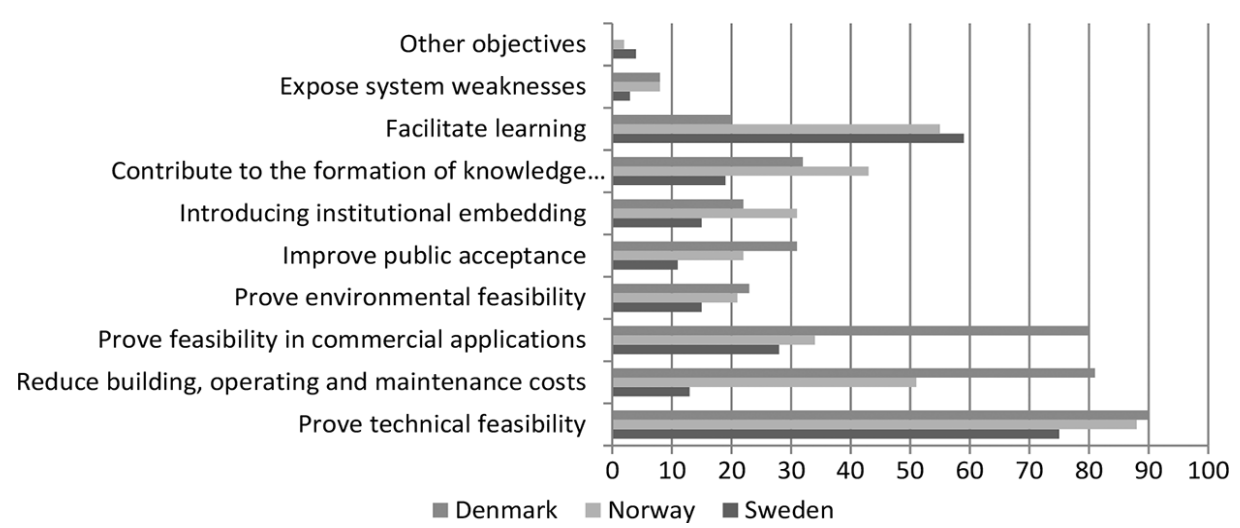

Note: Each project can have multiple aims

The analysis of the project aims revealed rather different priorities between the three countries (Figure 2). The main differences exist for following aims: facilitating learning, formation of knowledge networks, institutional embedding, public acceptance, commercial feasibility and reduction of costs. These different project priorities were addressed in the interviews with the programme managers. For this paper, the contribution to the formation of knowledge networks was especially relevant since the project wanted to reveal the effects of such projects on collaboration patterns.

Regarding the first research question, the analysis concentrated on collaboration patterns and the effects of such projects for networking of the involved actors. SNA was applied on the collaboration networks of the involved project partners at different points in time to see if there had been changes over time. The SNA was conducted for two periods, 2002-2008 and 2009-2012, to show whether any changes had occurred over time. It was distinguished between different types of partners such as private companies (incumbents vs. new entrants, large vs. small and medium-sized firms, domestic vs. foreign), universities, research institutes, non-governmental organisations, municipalities, regional and national administration, public funding agencies and other public agencies. It was distinguished between national and international collaboration patterns based on the localisation of the partners.

The SNA identified about 360 nodes in the Danish projects, 340 nodes in the Norwegian projects, and 190 nodes in the Swedish projects. Key statistical indicators are given for all three countries and include:

- Number of projects analysed.

- Number of interlinking projects and share of all projects.

- Number of projects with foreign partner and share of all projects.

- Number of sub-networks.

- Number of networked nodes. 
- Average network density.

- Fragmentation of the network.

- Size of largest sub-network measured in number of nodes based on x projects and share of all projects and of the whole network.

SNA techniques to measure different types of centrality in the networks were applied, such as Freeman's betweenness centrality and degree centrality. Betweenness centrality is defined as the number of times a node acts as a bridge along the shortest path between two other nodes (Freeman, 1977). This means that the higher the number of times acting as a bridge, the greater the centrality of the node. Degree centrality is defined as the number of links of any individual node has (Borgatti, 2005). The top 10 actors in each country based on both centrality measures are given for each country.

The SNA calculations were made with the SNA software, Ucinet, developed by Borgatti, Everett and Freeman (2002). The SNA maps have been created with the help of the software NetDraw developed by Borgatti (2002). The SNA maps were based on betweenness centrality measures and spring-embedding is applied as the graphtheoretical layout.

Regarding the second research question, results of qualitative research analyses were used. Interviews and focus groups with programme coordinators in the three countries were used as the empirical basis: two focus groups with programme managers in Norway, and five individual interviews with programme managers about programme priorities, project collaboration, user involvement, project design and planning, monitoring and evaluation of projects, and maturity of technology (Klitkou et al., 2014). In the focus groups, the participants discussed policy implications of the SNA. For this paper, the sections on programme priorities, project collaboration and user involvement are used. The results for the different programmes are summarised. At a final workshop with programme managers in Norway, the policy implications of the research results were discussed. These policy conclusions were derived from an analysis of the results guided by the theoretical framework (Table 2).

Table 2 List of programmes covered by focus groups and interviews with programme managers

\begin{tabular}{ll}
\hline Denmark & Energy development and demonstration programme, EDDP \\
& Green Labs DK \\
& Test scheme for EVs \\
Norway & Enova SF \\
& Innovation Norway, environmental technology financing scheme \\
& Research Council of Norway, ENERGIX \\
& Transnova \\
Sweden & Swedish Energy Agency, demonstration programme for more efficient biogas \\
& production \\
& Swedish Energy Agency, demonstration programme for EVs \\
\hline
\end{tabular}


Concerning the third research question, statistical data were used from the statistical agencies of the three countries related to registered personal electric vehicles (EVs) and the interviews with the programme managers (test scheme for EVs, Transnova, Swedish Energy Agency, and demonstration programme for EVs).

\section{Results}

\subsection{SNA of collaboration in demonstration projects}

\subsubsection{Comparative analysis}

In the Danish projects, 354 networked nodes were identified, 296 nodes in the Norwegian projects and 169 nodes in the Swedish projects. A comparative overview of the collaboration patterns of all demonstration projects with at least two partners and which commenced in the period 2002-2012 for the three countries is provided in the following. The comparative analysis of the network patterns reveals clear differences between the three countries (Tables 2 and 3):

- In Denmark, more than twice as many projects existed in this period compared to Norway and Sweden.

- The numbers of actors differ especially between Denmark and Sweden.

- The proportion of projects, based on collaboration between at least two partners, is much lower in Sweden compared to Denmark and Norway.

- The network density is highest in Denmark and lowest in Sweden.

- The size of the largest sub-network includes most actors in Denmark (93\%) compared to in Sweden (51\%).

- Norway has a much higher number of sub-networks than Denmark and Sweden which can be an indicator of fragmentation.

- The share of projects with international partners is much lower in Sweden compared to Denmark and Norway (Table 3).

Table 3 Comparative analysis of SNA results for demonstration projects funded in Denmark, Norway and Sweden between 2002 and $2012(N=433)$

\begin{tabular}{lccc}
\hline & Denmark & Norway & Sweden \\
\hline Number of projects analysed & 224 & 107 & 102 \\
$\begin{array}{l}\text { Number of interlinking } \\
\text { projects }\end{array}$ & $\begin{array}{c}\text { (86 (83\% of all } \\
\text { projects })\end{array}$ & $86(80 \%$ of all & $38(37 \%$ of all \\
$\begin{array}{l}\text { Number of projects with } \\
\text { foreign partner }\end{array}$ & 34 projects $)$ & projects $)$ \\
\hline
\end{tabular}


Table 3 Comparative analysis of SNA results for demonstration projects funded in Denmark, Norway and Sweden between 2002 and $2012(N=433)$ (continued)

\begin{tabular}{lccc}
\hline & Denmark & Norway & Sweden \\
\hline Number of sub-networks & 9 & 24 & 12 \\
Number of networked nodes & 354 & 296 & 169 \\
Average network density & 0.0687 & 0.0401 & 0.0155 \\
Size of largest sub-network & $\begin{array}{c}328 \text { nodes (93\% } \\
\text { of network) }\end{array}$ & $\begin{array}{c}237 \text { nodes (70\% } \\
\text { of network) }\end{array}$ & $\begin{array}{c}87 \text { nodes (51\% of } \\
\text { network) }\end{array}$ \\
\hline
\end{tabular}

International collaboration relations show an unbalanced pattern. Compared to both Sweden and Denmark, Norway has a higher degree of collaboration with foreign organisations: almost every fourth project $(22 \%)$ includes at least one foreign partner, while the Swedish projects fund much fewer projects with international participation. Partners from 18 countries participate in the Norwegian projects. The most important partner countries are Sweden (six projects), Denmark, Germany, and UK (each five projects). Denmark had no project involving Norwegian participation, but strong collaboration with Germany and Sweden. Sweden had one project with a Norwegian partner and three with a Danish partner.

\subsubsection{Main organisations}

The main organisations in the three countries were identified applying degree centrality and betweenness centrality measures, distinguishing between different types of partners (the names of the Norwegian organisations are anonymised) (Table 4).

Table 4 The main organisations in the three countries based on measurements for Freeman's Betweenness Centrality

\begin{tabular}{|c|c|c|c|c|c|}
\hline \multicolumn{2}{|l|}{ Denmark } & \multicolumn{2}{|c|}{ Norway } & \multicolumn{2}{|l|}{ Sweden } \\
\hline $\begin{array}{l}\text { Danmarks } \\
\text { Tekniske } \\
\text { Universitet }\end{array}$ & 19683,572 & NoRD_Inst_7 & 8522.566 & Volvo Trucks & 1476,000 \\
\hline $\begin{array}{l}\text { Teknologisk } \\
\text { Institut }\end{array}$ & 14471,109 & NoI_LC_21 & 8221.103 & Stockholms Stad & 1220,000 \\
\hline $\begin{array}{l}\text { Aalborg } \\
\text { Universitet }\end{array}$ & 11802,664 & No_NGO_6 & 7247.182 & $\begin{array}{l}\text { Energitekniskt } \\
\text { Centrum i Piteå }\end{array}$ & 949,000 \\
\hline Danfoss A/S & 5573,197 & NoRD_Inst_18 & 4546.615 & Umeå Universitet & 760,000 \\
\hline DONG Energy & 5416,178 & No_Munic_10 & 3319.000 & $\begin{array}{c}\text { Kungliga Tekniska } \\
\text { Högskolan }\end{array}$ & 644,000 \\
\hline $\begin{array}{l}\text { Aarhus } \\
\text { Universitet }\end{array}$ & 4008,290 & NoNE_SME_72 & 3092.056 & $\begin{array}{l}\text { Haldor Topsøe, } \\
\text { Denmark }\end{array}$ & 512,667 \\
\hline
\end{tabular}


Table 4 The main organisations in the three countries based on measurements for Freeman's Betweenness Centrality (continued)

\begin{tabular}{|c|c|c|c|c|c|}
\hline \multicolumn{2}{|l|}{ Denmark } & \multicolumn{2}{|c|}{ Norway } & \multicolumn{2}{|l|}{ Sweden } \\
\hline $\begin{array}{l}\text { PlanEnergi } \\
\text { A.M.B.A. }\end{array}$ & 2326,469 & NoNE_SME_26 & 3085.621 & E.ON Sverige & 405,000 \\
\hline $\begin{array}{l}\text { Haldor } \\
\text { Topsøe A/S }\end{array}$ & 2000,342 & NoNE_SME_57 & 1791.000 & $\begin{array}{l}\text { SP Sveriges Tekniska } \\
\text { Forskningsinstitut AB }\end{array}$ & 405,000 \\
\hline IRD A/S & 1823,423 & NoI_SME_73 & 1600.000 & $\begin{array}{l}\text { Lunds tekniska } \\
\text { högskola }\end{array}$ & 252,000 \\
\hline $\begin{array}{l}\text { Københavns } \\
\text { Kommune }\end{array}$ & 1684,182 & No_Uni_1 & 1463.067 & $\begin{array}{l}\text { AB Storstockholms } \\
\text { Lokaltrafik }\end{array}$ & 221,333 \\
\hline
\end{tabular}

Note: For Norway, alphanumerical codes have been used. The codes of the organisation names are based on a combination of short codes for organisation categories and an ID number. New entrants are defined as starting not earlier than 2002. SMEs are defined as firms with less than 250 employees. The distribution of organisation categories can be seen in the Appendix. The most prominent types of organisations are Norwegian SMEs, both incumbent (104) and new entrants (73), followed by Norwegian incumbent large firms (23), foreign incumbent large firms (19) and Norwegian research institutes (15). ${ }^{1}$

In Denmark, mainly two types of organisations are active: universities (Danmarks Tekniske Universitet, Aalborg Universitet, Aarhus Universitet, and Københavns Universitet), and firms (DONG Energy, Haldor Topsøe A/S, Dantherm Power A/S, IRD $\mathrm{A} / \mathrm{S}$, and $\mathrm{H} 2$ Logic $\mathrm{A} / \mathrm{S}$ ). In addition, one R\&D institute (Teknologisk Institut) should be highlighted.

In Norway, there are mainly the following types of organisation: large incumbent companies (NoI_LC_21, NoI_LC_16), new entrants (NoNE_SME_26, NoNE_SME_72, NoNE_SME_48), one university (No_Uni_1), two R\&D institutes (NoRD_Inst_7, NoRD_Inst_18), a large municipality (No_Munic_10), and a non-governmental organisation (No_NGO_6).

In Sweden, mainly four types of organisation can be found: universities (Lund tekniska högskola, Kungliga Tekniska Högskolan, Högskolan Dalarna, Uppsala Universitet), firms (Vattenfall $\mathrm{R} \& \mathrm{D} \mathrm{AB}$, Seabased Industry $\mathrm{AB}$ ), and municipal organisations (Göteborgs gatu, Malmö Stad). In addition, other organisations can be highlighted (Test Site Sweden, Almi).

It can be concluded that in all three countries firms are fairly central in the networks while the role of universities is more central in Denmark and Sweden compared to Norway where R\&D institutes play a decisive role. The central position of municipal organisations in both Norway and Sweden, and the strong involvement of a NGO in Norway is of interest.

\subsubsection{Changes in network patterns}

The network patterns were analysed over time for all three countries. Here, the results for the Norwegian sub-networks for two periods are presented: early projects 2002-2008 and later projects 2009-2012, and comments on changes from the first to the second period. The division between the two periods is motivated by the introduction of new funding programmes after 2008 (Figure 3). 
Figure 3 Network of all Norwegian demonstration projects identified with more than one participant $(N=25)$, started between 2002 and 2008, based on betweenness centrality measures. Number of sub-networks: 9 (see online version for colours)
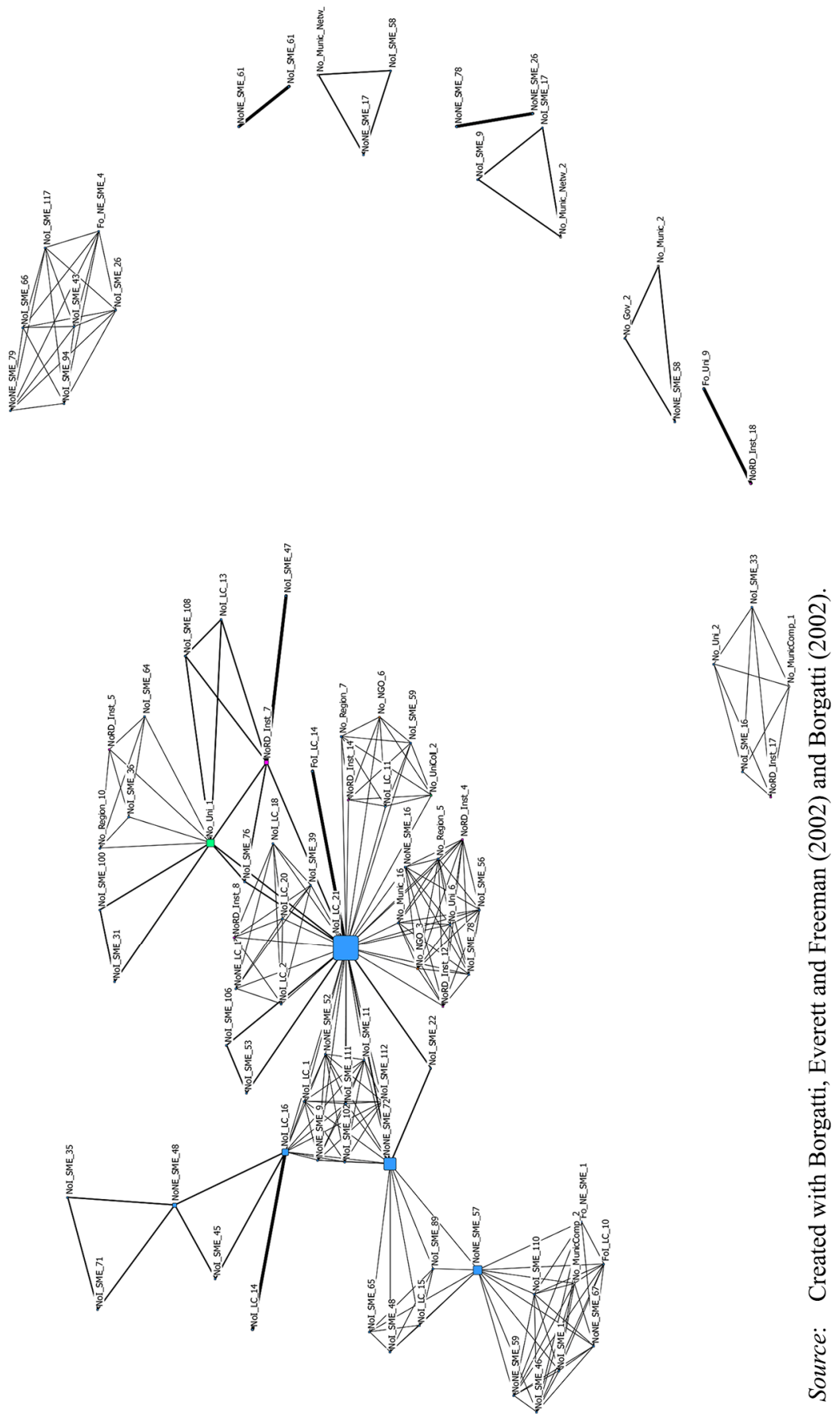


\subsubsection{Projects 2002-2008}

The SNA for the early Norwegian demonstration projects identified 92 connected nodes based on 25 of the 27 projects (93\% of all projects), which had more than one participant. The SNA identified nine sub-networks; three including just two partners. The density of the early Norwegian network is 0.0470 with a standard deviation of 0.0822 . Despite the low number of projects with foreign partners, a foreign university (Fo_Uni_9) and a foreign new entrant SME (Fo_NE_SME_4), are among the most central nodes.

Most central in terms of degree centrality and betweenness centrality in this period were a large Norwegian incumbent (NoI_LC_21, NoI_LC_16), a Norwegian university (No_Uni_1), a number of Norwegian SMEs, both incumbents (NoI_SME_47), new entrants (NoNE_SME_48, NoNE_SME_72, NoNE_SME_57), and a Norwegian research institute (NoRD_Inst_ 7 ).

\subsubsection{Projects 2009-2012}

The SNA for the later Norwegian projects identified 226 nodes based on 61 of 80 projects $(76 \%$ of all projects) which had more than one participant. The SNA identified 26 sub-networks; seven of these included just two partners. The density of this later Norwegian network is 0.0362 with a standard deviation of 0.0618 .

The number of sub-networks increased in the second period from 9 to 28 sub-networks, and the average density decreased from 0.0470 to 0.0362 . Both indicators can be interpreted as having fragmentation tendencies. One explanation for this fragmentation can be the different technological specialisation of the different actors. Another explanation can be the introduction of new support schemes for demonstration projects, which have funded other types of projects than the schemes in the earlier period. When analysing the project aims, 44 projects ( $45 \%$ of all networked projects) aimed to contribute to the formation of knowledge networks throughout the entire period; 34 of these projects commenced in the second period.

It is interesting to note that in the second period the main node in the network is no longer the large incumbent company (NoI_LC_21), but two Norwegian research institutes (NoRD_Inst_7, NoRD_Inst_18), a Norwegian NGO (No_NGO_6) and a Norwegian municipality (No_Munic_10), which have taken over the central position. Also important is the increasing proportion of foreign partners from $11 \%$ in the first period to 34\% in the second period. Again, a foreign university (Fo_Uni_3) is among the 10 main nodes, while other foreign actors are less prominent (Figure 4). 
Figure 4 Network of all Norwegian demonstration projects identified with more than one participant $(N=61)$, started between 2009 and 2012, based on betweenness centrality measures. Number of sub-networks: 28 (see online version for colours)

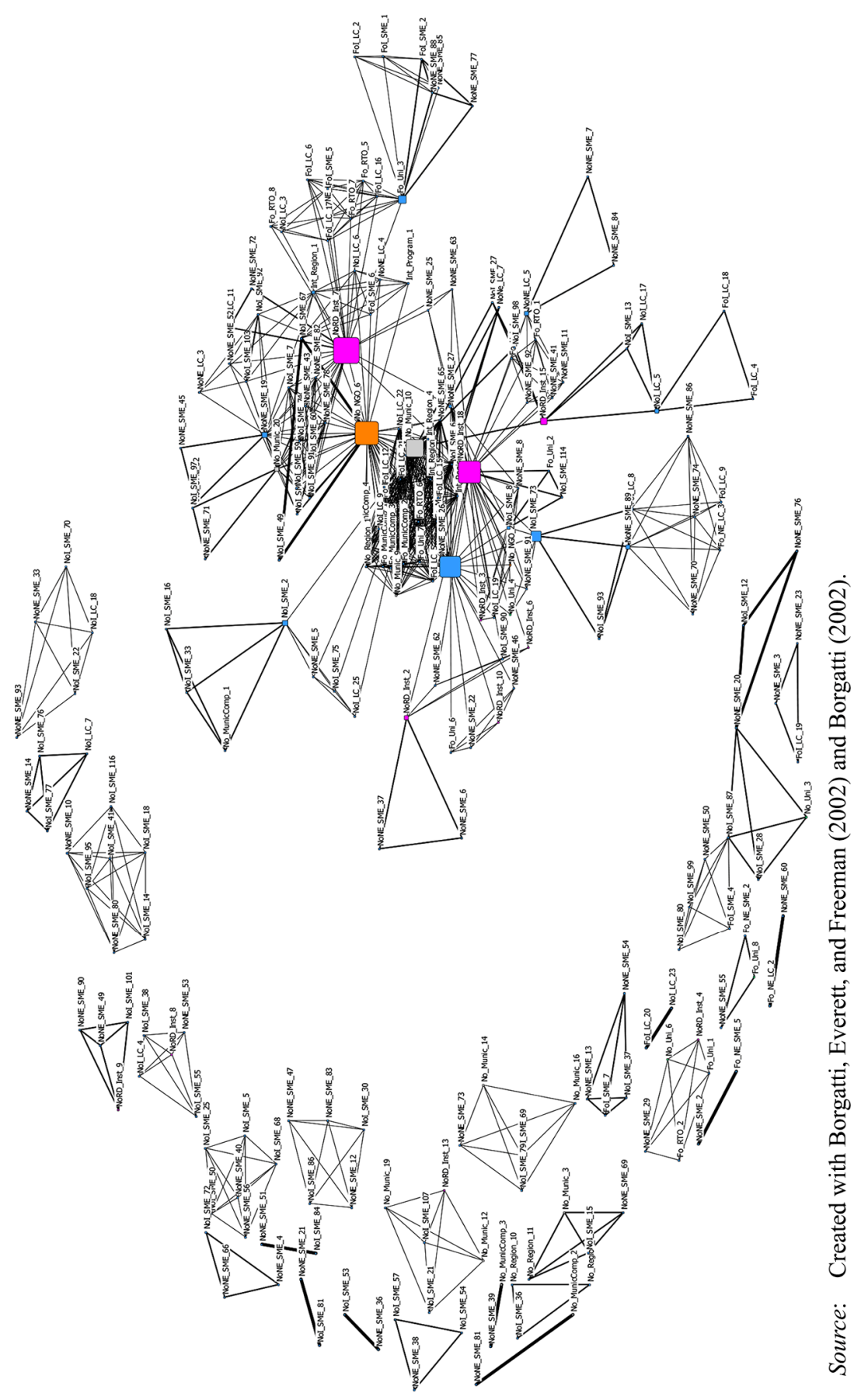




\subsection{Policy priorities of the funding programmes}

The second research question targets how Scandinavian demonstration programmes prioritise learning in international knowledge networks and user involvement. In the focus groups and interviews with programme managers, it was discussed how the programme objectives and priorities have been developed, who had been involved, and how national and international collaboration and user involvement have been addressed (Klitkou et al., 2014, p.51ff.). Table 5 summarises these results regarding objectives and prioritisation of collaboration and user involvement by the Scandinavian demonstration programmes.

Table 5 Objectives and prioritisation of collaboration and user involvement in Scandinavian demonstration programmes

\begin{tabular}{|c|}
\hline Denmark \\
\hline Energy development and demonstration programme, EDDP (since 2007) \\
\hline $\begin{array}{l}\text { Objective: Through support of development, demonstration and market introduction of new } \\
\text { energy technology support the energy policy goals about secure energy supply, independence } \\
\text { from fossil fuels, climate challenges, cleaner environment and cost efficiency. At the same time, } \\
\text { the programme shall strengthen business potentials to achieve growth and employment }\end{array}$ \\
\hline $\begin{array}{l}\text { Collaboration is regarded as an advantage by EDDP, but not an outspoken demand. International } \\
\text { collaboration and knowledge networks on energy technology are not in themselves a high } \\
\text { priority. EDDP has a priority to support collaboration between public and private actors. The } \\
\text { involvement of end-users of the technology is not always prioritised. This depends on the } \\
\text { technology and possible applications. }\end{array}$ \\
\hline Green Labs DK (since 2010) \\
\hline $\begin{array}{l}\text { Objective: The facilities shall enable testing and demonstration of the technologies under } \\
\text { realistic large-scale conditions. They shall build on Danish top expertise and be capable of } \\
\text { attracting both Danish and foreign actors. Green Labs DK shall strengthen business potentials to } \\
\text { achieve growth and employment. The programme supports the government's vision that } \\
\text { Denmark shall be a 'green technology lab' where green enterprises have the best framework } \\
\text { conditions }\end{array}$ \\
\hline $\begin{array}{l}\text { The programme prioritises collaboration. The facilities should give access to both Danish and } \\
\text { international actors. Public-private collaboration is supported mainly at the level of clusters and } \\
\text { not primarily at the level of single actors. Collaboration is prioritised because this can improve } \\
\text { the effects of the projects. User involvement is important in all technology and application areas. } \\
\text { Main users are companies and other technology developers which will use the test and } \\
\text { demonstration facilities in their product and technology development }\end{array}$ \\
\hline Test scheme for EVs (since 2012) \\
\hline $\begin{array}{l}\text { Objective: To contribute with new practical experiences with EVs and the related infrastructure. } \\
\text { The projects shall include fleets of EVs (not just single EVs) and EV fleet owners who operate a } \\
\text { number of EVs, such as public authorities, companies or organisations. Regarding infrastructure, } \\
\text { the scheme has focus on practical experience build-up, business models, and methods, and rules } \\
\text { for the interaction with the electricity system. The scheme supports also projects that undertake } \\
\text { analyses across projects or communicate results to the public }\end{array}$ \\
\hline $\begin{array}{l}\text { Collaboration is often an important element of the projects and a precondition for funding. } \\
\text { Public-private collaboration is supported by (among others) politicians, public authorities and } \\
\text { actors in the energy sector. User involvement is very important in this programme }\end{array}$ \\
\hline
\end{tabular}


Table 5 Objectives and prioritisation of collaboration and user involvement in Scandinavian demonstration programmes (continued)

\begin{tabular}{|c|}
\hline Norw \\
\hline Enova SF (since 2001) \\
\hline $\begin{array}{l}\text { Objective: Securing energy supply with renewable energy and reducing greenhouse gas } \\
\text { emissions. The aim is to introduce new technologies into the market by supporting the 'first } \\
\text { customers'. Three criteria for project acceptance: customer involvement, positive cash flow and } \\
\text { that the installation will be in operation for at least two years. Enova also prioritise projects with } \\
\text { a good potential for technology dissemination internationally. Enova's focus is on technology } \\
\text { which will help to achieve Norway's energy and climate targets }\end{array}$ \\
\hline $\begin{array}{l}\text { Aims to promote collaboration, and facilitate contact, particularly among SMEs. However, there } \\
\text { are no explicit requirements for cooperation, but the ability to complete the project is important. } \\
\text { Requires user involvement in all projects. Normally, the users should apply for funding, but } \\
\text { some industries such as the energy utilities are rather conservative, and therefore technology } \\
\text { providers have been accepted as applicants }\end{array}$ \\
\hline Innovation Norway, Environmental Technology Financing Scheme (since 2011) \\
\hline $\begin{array}{l}\text { Objective: Distinct focus on pilot- and demonstration projects for environmental technology. } \\
\text { The focus is on the pre-commercial phase and on involving large companies and strong } \\
\text { communities. The objective is to extract an environmental benefit and contribute to wealth } \\
\text { creation. Wealth creation is the primary goal, while reduction of greenhouse gases is a } \\
\text { secondary goal }\end{array}$ \\
\hline $\begin{array}{l}\text { Does not prioritise international projects in comparison to national projects. The most important } \\
\text { issue is that there is a demanding customer who wants to deploy the technology, that the pilot } \\
\text { plant is located in Norway and that a significant part of the value creation will take place in } \\
\text { Norway. The involvement of users is differing. Sometimes the applicant is the user. In any case, } \\
\text { it has to be verified that there is a customer who is willing to deploy the new technology }\end{array}$ \\
\hline Research Council of Norway, Renergi (now ENERGIX) (since 2004) \\
\hline $\begin{array}{l}\text { Objective: Coordinate basic and applied research on environmental energy technologies. } \\
\text { ENERGIX has five objectives: sustainable exploitation and use of renewable energy resources; } \\
\text { reduction of Norwegian and global greenhouse gas emissions; good national security of energy } \\
\text { supply; strengthening of innovation in energy related business; further development of } \\
\text { Norwegian energy research; finances and facilitates forums for renewable energy and energy } \\
\text { efficiency. ENERGIX does not fund demonstration projects as much as Renergi did }\end{array}$ \\
\hline $\begin{array}{l}\text { Favours cooperation only when this contributes to greater feasibility and national capacity } \\
\text { building }\end{array}$ \\
\hline $\begin{array}{l}\text { There is basically no requirement for user involvement, but dialogue with potential users is } \\
\text { required }\end{array}$ \\
\hline Transnova (since 2009) \\
\hline $\begin{array}{l}\text { The main objective is to reduce greenhouse gas emissions from the transport sector in Norway. } \\
\text { Transnova awards grants to projects mainly in the pilot- / demonstration phase, which contribute } \\
\text { to a transition to sustainable modes of transport. Transnova has as long-term goal reducing } \\
\text { barriers to reduce greenhouse gas emissions and contributing to knowledge sharing and business } \\
\text { development }\end{array}$ \\
\hline $\begin{array}{l}\text { Projects should contribute to knowledge-sharing and projects must have an effect. If the projects } \\
\text { can get this alone or in cooperation with national and international partners is secondary. } \\
\text { Transnova has collaborated with environmental NGOs and has funded a number of projects with } \\
\text { an NGO as a project leader. Transnova has a focus on the involvement of users. The focus on } \\
\text { interaction with users varies according to the kind of business that is applying }\end{array}$ \\
\hline
\end{tabular}


Table 5 Objectives and prioritisation of collaboration and user involvement in Scandinavian demonstration programmes (continued)

Sweden
Swedish Energy Agency, Demonstration programme for more efficient biogas production (since
2012)
Objective to support energy technology, which is environmentally friendly but which has not
achieved commercial competitiveness yet. The projects should contribute to increased
production and deployment of biogas, be favourable for the climate, and provide largest possible
climate effect in consideration of financial support received. The solutions should be energy
efficient and have potential for technical development and competitiveness
Collaboration is not an explicit goal but regarded as positive. It has been decisive to identify
possible users of the demonstrated technology since the programme has a focus on increased
biogas production and deployment of biogas. There is a broad range of users: from
municipalities to single farmers who both produce and deploy biogas
Swedish Energy Agency, Demonstration programme for EVs (since 2011)
The programme has the long-term vision to replace fossil fuel transport with e-mobility. The
programme has the following objectives: (1) demonstrate chargeable EVs and charging
infrastructure to support an electrification of the vehicle fleet, (2) identify and eventually
eliminate barriers for large-scale introduction of BEVs on the Swedish market, and (3) create an
information channel to disseminate relevant research and information regarding e-mobility
Collaboration has not been a top priority of the programme. However, the programme
recommends the applicants from industry to involve researchers from universities to increase the
research status of the project. Collaboration between industry and municipal actors has not been
that frequent, but the programme will facilitate this in the future. The programme has a focus on
involvement of users and the institutional embedding of the technology. In almost all the
projects users have been involved, with the exception of financing models or similar

The comparative analysis of prioritisation of collaboration by the funding programmes showed not only some clear similarities but also a number of differences. Here, the following issues are highlighted:

1 The influence of the NIS on national collaboration patterns.

2 Collaboration with foreign partners.

3 The balance between sustainability and competiveness targets.

4 The control of significant intellectual property.

5 User involvement.

6 The involvement of interest organisations and local authorities or municipalities.

In the comparative analysis, it was revealed that prioritisation of collaboration is addressed somewhat differently in the three countries. National collaboration patterns vary due to different NIS, such as the balance between universities and R\&D institutes outside universities, the role of NGOs, the existence of large R\&D-based incumbents or the dominance of SMEs. The comparison of the Scandinavian demonstration programmes reveals only minor differences in the prioritisation of international collaboration. Therefore, the different involvement of foreign partners, as documented in the SNA, has to be explained by other factors. Other explanations could be the scarcity of 
resources or different experiences regarding the usefulness of international collaboration, but this needs further research.

National funding programmes for demonstration and trial projects for sustainable energy and transport solutions have to balance between two priorities:

1 Supporting the transition towards more sustainable solutions.

2 Strengthening the competitiveness of national actors.

However, the focus on competitiveness is not so strong in the Danish and Swedish programmes as in some of the Norwegian programmes. There are also differences between the Norwegian support schemes. While Enova has clear climate targets as its highest priority, the environmental technology financing scheme has national competitiveness as highest priority and Transnova has a combination of both. Nevertheless, there are a number of differences between the countries. Support schemes for e-mobility in Sweden and Denmark prioritise e-mobility as a solution for achieving climate targets while in Norway the supported projects are also required to show a positive influence on business.

Several Norwegian support schemes allow companies to retain control of significant intellectual property and are not required to disclose significant technology to the public. Similarly, the Danish test scheme for EVs has experience with firms, which avoids their knowledge being transferred to their competitors. This makes collaboration difficult.

There were changes in the direction of a more common understanding regarding user involvement, something which is central to all funding programmes. This is especially manifest in the most recently established programmes on e-mobility in all three countries. There are differences concerning who the users can be, i.e., the end-users of EVs can be individual customers or fleet owners; the user of a new energy technology can be an electricity facility or a company, which is integrating the technology into its operations, etc. Consequently, it is difficult to draw general conclusions for all users.

Another interesting question is whether the Scandinavian demonstration projects are based on collaboration between the usual actors such as firms and R\&D organisations, or whether they also include other types of societal actors such as NGOs, local authorities and private foundations. The analysis revealed that NGOs played an important role only in the Norwegian network. Municipalities and local authorities were involved actively in demonstration projects in all three countries, but especially in Sweden and Norway. This is confirmed by the SNA results and the feedback from projects during data collection. Representatives from Swedish local authorities and municipalities often expressed that it was on local and regional level that the 'real' work was done, while the national level and companies came later. The Danish test scheme for EVs had a dialogue with interest organisations and supports collaborative projects connecting firms with local authorities.

The discussions with the programme managers resulted in policy conclusions for funding programmes (Klitkou et al., 2015). These discussions were guided by an analysis of the empirical results - both the qualitative and the SNA results - and are summarised in Table 6. The table indicates which elements of our theoretical framework have been relevant for the respective conclusions. 
Table 6 Policy conclusions for funding programmes

\begin{tabular}{ll}
\hline Policy conclusions for funding programmes & Theoretical framework \\
\hline $\begin{array}{l}\text { Support a number of projects and not just one big } \\
\text { project to facilitate the demonstration of several } \\
\text { alternative solutions }\end{array}$ & $\begin{array}{l}\text { SNM on supporting many experiments } \\
\text { to facilitate niche development }\end{array}$ \\
$\begin{array}{l}\text { Facilitate learning across projects to contribute to } \\
\text { knowledge sharing }\end{array}$ & $\begin{array}{l}\text { SNM on facilitating learning processes } \\
\text { across experiments }\end{array}$ \\
$\begin{array}{l}\text { Address the need of companies to retain the } \\
\text { intellectual property rights in balance with the } \\
\text { sustainability targets of the programmes }\end{array}$ & Innovation system theory on IPR \\
$\begin{array}{l}\text { Facilitate - when relevant - the dialogue with NGOs } \\
\text { Target more institutional embedding of new }\end{array}$ & $\begin{array}{l}\text { SNM on experiments and how they } \\
\text { bridge between variation and selection } \\
\text { environments }\end{array}$ \\
$\begin{array}{l}\text { technological solutions to improve learning about } \\
\text { and diffusion of the technology }\end{array}$ & $\begin{array}{l}\text { SNM on importance of institutional } \\
\text { embedding for niche development }\end{array}$ \\
$\begin{array}{l}\text { Strengthen private-public collaboration, especially at } \\
\text { the local level }\end{array}$ & $\begin{array}{l}\text { Transition management on negotiation } \\
\text { and coordination between different }\end{array}$ \\
$\begin{array}{l}\text { Coordinate their efforts at the national level to secure } \\
\text { optimal conditions for the supported projects }\end{array}$ & $\begin{array}{l}\text { Transition management on levels of } \\
\text { governance }\end{array}$ \\
$\begin{array}{l}\text { Coordinate their efforts across national borders to } \\
\text { achieve stronger and more successful projects and } \\
\text { collaboration across the Scandinavian borders }\end{array}$ & $\begin{array}{l}\text { Transition management on levels of } \\
\text { governance }\end{array}$ \\
\hline
\end{tabular}

\subsection{Contribution of demonstration projects to transition processes}

Finally, we assess how such demonstration projects have contributed to transition processes. Here it is not possible to go into detail for all technologies, but the paper concentrates on the example of e-mobility in the three countries. For Denmark and Sweden, a low level of deployment can be observed in 2008 with 142 battery EVs in Denmark and 129 in Sweden. In Norway, the starting point was already higher with almost 1,700 vehicles. The coordinated introduction of different types of incentives and of demonstration projects funded by the funding scheme Transnova in Norway strengthened this trend. In 2014, Norway had registered almost 39,000 vehicles, while Denmark and Sweden had 1,500 and 2,200, respectively. The favourable results in Norway can be explained by the coordination involving different governance levels thereby facilitating the institutional embedding of e-mobility with a broad range of incentives. These resulted in increased demand for e-mobility, the instalment of an EV charging infrastructure in different parts of the country, and the involvement of NGOs and of local actors (user groups and municipalities). It can be concluded that demonstration projects alone cannot facilitate a transition process: they have to be part of a broader process involving interaction between the various levels of governance and the involvement and interaction of user groups, and new types of actors, such as NGOs or user groups (Figure 5). 
Figure 5 Number of registered electric person vehicles and share of all registered person vehicles, 2008-2014. (see online version for colours)

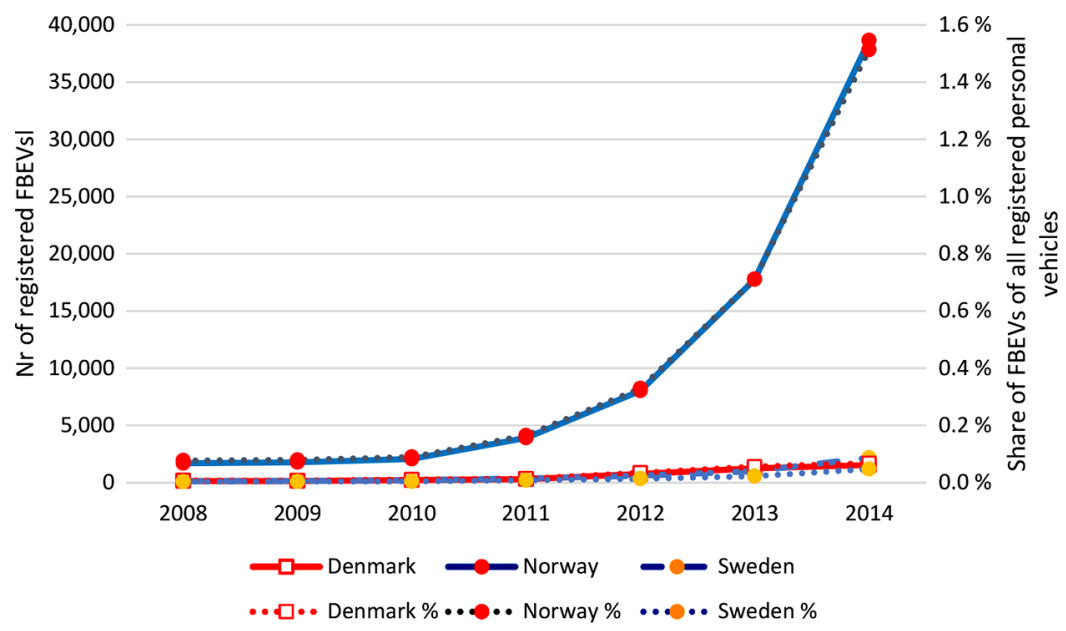

Source: Statistics Norway, Statistics Denmark, Statistics Sweden

\section{Conclusions}

This paper presents results of an analysis of effects of demonstration projects in transition processes to sustainable energy and transport in the Scandinavian countries on the development of knowledge networks and on interaction with users, which are highlighted as two of the main outcomes of demonstration projects. Public funding of demonstration and trial projects is relatively well-developed policy instruments for the transition towards more sustainable energy and transport systems in the Scandinavian countries. However, the three countries have used such instruments to a different extent and with different priorities.

This paper concentrated on the formation of broad and aligned networks and collaboration patterns, including the involvement of industrial users and customers, and analysed how public agencies prioritised networking and user involvement in their funding programmes of demonstration and trial projects.

In the first research question, we enquired into the success of Scandinavian demonstration projects in their contribution to the development of knowledge networks for sustainable energy and transport transitions. It could be concluded, that the comparative analysis of the network patterns revealed clear differences between the three countries regarding the numbers of projects, actors, share of collaborative projects, network density, fragmentation and collaboration with international partners. International collaboration relations showed an unbalanced pattern. Norway had a higher degree of collaboration with foreign organisations compared to both Sweden and Denmark. Collaboration with Norwegian partners were almost not-existent in projects funded by Danish or Swedish funding schemes, while projects funded by Norwegian funding schemes in supported collaboration with Swedish or Danish partners.

National collaboration patterns are different due to different NIS. These different NIS were explained by differences regarding the balance between universities and R\&D 
institutes, the role of NGOs, the existence of large R\&D-based incumbents or the dominance of SMEs. However, the different involvement of foreign partners as shown by the SNA seems not to be the result of different political prioritisation and requires further research.

The Scandinavian funding programmes for demonstration and trial projects related to sustainable energy and transport solutions interact with the respective R\&D funding programmes. In some cases, they are even part of such programmes. There is also a need for analysing the funding programmes for demonstration and trial projects in interaction with other policy instruments, such as fiscal instruments. This has not been the focus of this paper.

Scandinavian demonstration projects are often based on collaboration between firms and $\mathrm{R} \& \mathrm{D}$ organisations, but the networks also include other types of societal actors such as NGOs and municipal organisations. In all three countries, firms are central in the networks, while the role of universities is more central in Denmark and Sweden than in Norway where R\&D institutes outside universities play a decisive role. The central position of municipal organisations in both Norway and Sweden and the strong involvement of an NGO in Norway is interesting. This NGO initiated several demonstration projects.

Pilot, demonstration and test projects frequently involve collaboration between quite diverse actors. Some are private companies interested in exploring commercial opportunities; others are research institutions interested in carrying out innovative research. Yet others are NGOs interested in pursuing certain political goals. In addition to differences in goals, these organisations vary in size and have different organisational cultures and decision-making processes. Some have worked together previously and have an established relationship while others met for the first time during the project. These and other factors affect how well the different actors work together and whether the pilot, demonstration or test projects are successful.

From the qualitative analysis, it could be concluded that several factors affect collaboration in pilot, demonstration and test projects. In general, similarities between the participants are favourable. Both similarities in size, organisational culture and educational background were considered to be favourable by most participants. Nevertheless, differences in some aspects (educational background) do not necessarily hamper collaboration if the participants find common ground on other aspects (organisational culture). In general, most participants found ways of combining different goals. Nevertheless, in some instances, the participants had to undertake considerable effort in order to find 'common ground,' and move the project forward.

The second research question asked whether Scandinavian demonstration programmes prioritise learning in international knowledge networks and user involvement. While the SNA revealed that Norway has a higher degree of collaboration with foreign organisations compared to both Sweden and Denmark, the comparative analysis of prioritisation of collaboration by the funding programmes shows that there are nevertheless some clear similarities. National funding programmes for demonstration and trial projects for sustainable energy and transport solutions have to balance between two priorities: sustainability and competitiveness. However, the focus on competitiveness is not that strong in the Danish and Swedish programmes as in some of the Norwegian programmes, but there are also differences between the Norwegian support schemes.

User involvement is central to all the funding programmes. However, there are differences related to who the users can be, i.e., the end-users of EVs can be individual 
customers or fleet owners; the user of a new energy technology can be a power plant or a company, which is integrating technology in its operations, etc. Therefore, it is difficult to draw general conclusions for all types of users.

In the third research question, it was asked how the various kinds of demonstration project contributed to facilitating transition processes. It can be concluded that demonstration projects alone cannot facilitate a transition process; they have to be part of a broader process, involving the interaction between the different levels of governance and the involvement and interaction of user groups, and new types of actors.

\section{Acknowledgements}

The work was supported by the Research Council of Norway, as funding of the project 'Role of demonstration projects in innovation: transition to sustainable energy and transport', Project Number 224920/D00. I would like to thank Mads Borup from the Technical University of Denmark, Arne Fevolden from NIFU, and Alexandra Nikoleris and Teis Hansen from Lund University, Sweden, for their contributions to this paper.

\section{References}

Asheim, B.T. and Gertler, M. (2005) 'The Geography of Innovation. Regional Innovation Systems', in Fagerberg, J. Mowery, D.C. and Nelson, R.R. (Eds.): The Oxford Handbook of Innovation, Oxford University Press, Oxford, pp.291-317.

Bergek, A., Hekkert, M. and Jacobsson, S. (2008) 'Functions in Innovation Systems: A Framework for Analysing Energy System Dynamics and Identifying Goals for System-Building Activities by Entrepreneurs and Policymakers', in Foxon, T.J., Köhler, J. and Oughton, C. (Eds.): Innovation for a Low Carbon Economy: Economic, Institutional and Management Approaches, Edward Elgar, Cheltemham, UK, pp.79-111.

Bitard, P., Edquist, C., Hommen, L. and Rickne, A. (2008) 'Reconsidering the Paradox of High R\&D Input and Low Innovation: Sweden', in Edquist, C. and Hommen, L. (Eds.): Small Country Innovation Systems: Globalization, Change and Policy in Asia and Europe, Edward Elgar, Cheltenham, UK, pp.237-280.

Borgatti, S.P. (2002) NetDraw: Graph Visualization Software, Analytic Technologies, Harvard.

Borgatti, S.P. (2005) 'Centrality and network flow', Social Networks, Vol. 27, pp.55-71.

Borgatti, S.P., Everett, M.G. and Freeman, L.C. (2002) Ucinet for Windows: Software for Social Network Analysis, Analytic Technologies, Harvard.

Borup, M., Andersen, P.D., Gregersen, B. and Tanner, A.N. (2009) Ny Energi og Innovation $i$ Danmark, Jurist- og Økonomforbundets Forlag, København.

Borup, M., Andersen, P.D., Jacobsson, S. and Midttun, A. (2008) Nordic Energy Innovation Systems - Patterns of Need Integration and Cooperation, Nordic Energy Research, Oslo.

Borup, M., Jacobsen, D.C. and Bagratunjan, A. (2013) Spørgeskemaundersøgelse om Innovation og Samspil på Energiområdet - EIS Survey 2011, DTU, Copenhagen.

Carlsson, B. and Stànkiewicz, R. (1991) 'On the nature, function, and composition of technological systems', Journal of Evolutionary Economics, Vol. 1, No. 2, pp.93-118.

Christensen, J.L., Gregersen, B., Johnson, B., Lundvall, B.-Å. and Tomlinson, M. (2008) 'An NSI in Transition? Denmark', in Edquist, C. and Hommen, L. (Eds.): Small Country Innovation Systems: Globalization, Change and Policy in Asia and Europe, Edward Elgar, Cheltenham, UK, pp.403-441.

Coenen, L., Benneworth, P. and Truffer, B. (2012) 'Toward a spatial perspective on sustainability transitions', Research Policy, Vol. 41, No. 6, pp.968-979. 
Coenen, L. and Díaz Lopez, F.J. (2010) 'Comparing systems approaches to innovation and technological change for sustainable and competitive economies: an explorative study into conceptual commonalities, differences and complementarities', Journal of Cleaner Production, Vol. 18, No. 12, pp.1149-1160.

Cooke, P. (2001) 'Regional innovation systems, clusters, and the knowledge economy', Industrial and Corporate Change, Vol. 10, No. 4, pp.945-974.

Dannemand Andersen, P., Cramer-Petersen, C., Harnes, K.N., Klitkou, A. and Nikoleris, A. (2014) Inventory of Demonstration and Trial Projects in Sustainable Energy and Transport in Scandinavia, Technical University of Denmark, DTU Management Engineering, Lyngby.

Edquist, C. and Hommen, L. (2008) Small Country Innovation Systems: Globalization, Change and Policy in Asia and Europe, Edward Elgar, Cheltenham, UK.

Freeman, C. (2002) 'Continental, national and sub-national innovation systems - complementarity and economic growth', Research Policy, Vol. 31, pp.191-211.

Freeman, L.C. (1977) 'A set of measures of centrality based on betweenness', Sociometry, Vol. 40, No. 1, pp.35-41.

Granstrand, O. (2005) 'Innovation and Intellectual Property Rights', in Fagerberg, J., Mowery, D.C. and Nelson, R.R. (Eds.): The Oxford Handbook of Innovation, Oxford University Press, Oxford, pp.266-290.

Granstrand, O. (2006) 'Intellectual Property Rights for Governance in and of Innovation Systems', in Andersen, B. (Ed.): Intellectual Property Rights: Innovation, Governance and the Institutional Environment, Edward Elgar, Cheltenham, UK, pp.311-343.

Grønning, T., Moen, S.E. and Olsen, D.S. (2008) 'Low Innovation Intensity, High Growth and Specialized Trajectories: Norway', in Edquist, C. and Hommen, L. (Eds.): Small Country Innovation Systems: Globalization, Change and Policy in Asia and Europe, Edward Elgar, Cheltenham, UK, pp.281-318.

Harborne, P. and Hendry, C. (2009) 'Pathways to commercial wind power in the US, Europe and Japan: the role of demonstration projects and field trials in the innovation process', Energy Policy, Vol. 37, No. 9, pp.3580-3595.

Hendry, C., Harborne, P. and Brown, J. (2010) 'So what do innovating companies really get from publicly funded demonstration projects and trials? Innovation lessons from solar photovoltaics and wind', Energy Policy, Vol. 38, No. 8, pp.4507-4519.

Hoogma, R. (2000) Exploiting technological niches, Thesis, Twente University, Enschede.

Hoogma, R., Kemp, R., Schot, J. and Truffer, B. (2002) Experimenting for Sustainable Transport Experimenting for Sustainable Transport: The Approach of Strategic Niche Management, Routledge, London, New York.

Kallerud, E., Amanatidou, E., Upham, P., Nieminen, M., Klitkou, A., Olsen, D.S., Toivanen, M.L., Oksanen, J. and Scordato, L. (2013) Dimensions of Research and Innovation Policies to Address Grand and Global Challenges, NIFU, Oslo.

Kamp, L.M., Smits, R.E.H.M. and Andriesse, C.D. (2004) 'Notions on learning applied to wind turbine development in the Netherlands and Denmark', Energy Policy, Vol. 32, No. 14, pp.1625-1637.

Kemp, R., Loorbach, D. and Rotmans, J. (2007) 'Transition management as a model for managing processes of co-evolution towards sustainable development', International Journal of Sustainable Development and World Ecology, Vol. 14, No. 1, pp.78-91.

Kemp, R., Schot, J. and Hoogma, R. (1998) 'Regime shifts to sustainability through processes of niche formation: the approach of strategic niche management', Technology Analysis \& Strategic Management, Vol. 10, No. 2, pp.175-195.

Klitkou, A., Borup, M., Fevolden, A. and Nikoleris, A. (2014) Scandinavian Demonstration Projects for Sustainable Energy and Transport: Their Contribution to the Formation of Broad and Aligned Networks, NIFU, Oslo. 
Klitkou, A., Coenen, L., Dannemand Andersen, P., Fevolden, A., Hansen, T., Nikoleris, A. and Olsen, D.S. (2013) 'Role of demonstration projects in innovation: transition to sustainable energy and transport', Paper Presented at the 4th International Conference on Sustainability Transitions, Zurich.

Klitkou, A., Coenen, L., Dannemand Andersen, P., Fevolden, A., Hansen, T., Nikoleris, A. and Olsen, D.S. (2015) InnoDemo Policy Brief, NIFU, Oslo.

Loorbach, D. (2007) Transition Management: New Mode of Governance for Sustainable Development, International Books, Utrecht.

Loorbach, D. and Rotmans, J. (2010) 'The practice of transition management: examples and lessons from four distinct cases', Futures, Vol. 42, No. 3, pp.237-246.

Lundvall, B.-Å. (Ed.) (1992a) National Innovation Systems: Towards a Theory of Innovation and Interactive Learning, Pinter, London.

Lundvall, B.-Å. (Ed.) (1992b) National Systems of Innovation: Towards a Theory of Innovation and Interactive Learning, Pinter Publishers, London.

Malerba, F. (Ed.) (2004) Sectoral Systems of Innovation: Concepts, Issues and Analyses of Six Major Sectors in Europe, Cambridge University Press, Cambridge.

Nelson, R.R. (Ed.) (1993) National Systems of Innovation: A comparative Study, Oxford University Press, Oxford.

OECD. (Ed.) (2002) Dynamising National Innovation Systems, OECD, Paris.

Raven, R. (2005) Strategic Niche Management for Biomass: A Comparative Study on the Experimental Introduction of Bioenergy Technologies in the Netherlands and Denmark, PhD Thesis, Technische Universiteit Eindhoven, Eindhoven.

Rip, A. (1995) 'Introduction of new technologies: making use of recent insights from sociology and economics of technology', Technology Analysis \& Strategic Management, Vol. 7, No. 4, pp.417-431.

Smith, A., Stirling, A. and Berkhout, F. (2005) 'The governance of sustainable socio-technical transitions', Research Policy, Vol. 34, pp.1491-1510.

Smith, A., Voss, J.-P. and Grin, J. (2010) 'Innovation studies and sustainability transitions: the allure of the multi-level perspective and its challenges', Research Policy, Vol. 39, No. 4, pp.435-448.

Tanner, A.N., Borup, M., Andersen, P.D. and Gregersen, B. (2009) Samspil, Innovation og Kompetenceudvikling på det danske Energiområde - Resultater af en Spørgeskemaundersøgelse, DTU, Lyngby.

Verheul, H. and Vergragt, P.J. (1995) 'Social experiments in the development of environmental technology - a bottom-up perspective', Technology Analysis \& Strategic Management, Vol. 7, No. 3, pp.315-326.

\section{Appendix}

${ }^{1}$ Appendix 1 Distribution of types of organisations

\begin{tabular}{lcc}
\hline Type of organisation & Short code & Number of organisations \\
\hline Foreign incumbent large firm & FoI_LC & 19 \\
Foreign incumbent SME & FoI_SME & 7 \\
Foreign municipal company & Fo_MunicComp & 5 \\
Foreign new entrant, large firm & Fo_NE_LC & 3 \\
Foreign new entrant, SME & Fo_NE_SME & 5 \\
\hline
\end{tabular}


${ }^{1}$ Appendix 1 Distribution of types of organisations (continued)

\begin{tabular}{lcc}
\hline Type of organisation & Short code & Number of organisations \\
\hline Foreign RTO & Fo_RTO & 6 \\
Foreign University & Fo_Uni & 8 \\
International programme & Int_Progr & 1 \\
International region & Int_Region & 4 \\
Norwegian governmental unit & No_Gov & 1 \\
Norwegian incumbent large firm & NoI_LC & 23 \\
Norwegian incumbent SME & NoI_SME & 104 \\
Norwegian municipal company & No_MunicComp & 3 \\
Norwegian municipal network & No_Munic_Netw & 2 \\
Norwegian municipality & No_Munic & 9 \\
Norwegian new entrant SME & NoNE_SME & 73 \\
Norwegian new entrant, large firm & NoNE_LC & 6 \\
Norwegian NGO & No_NGO & 3 \\
Norwegian R\&D institute & NoRD_Inst & 15 \\
Norwegian Region & No_Reg & 6 \\
Norwegian University & No_Uni & 5 \\
Norwegian University college & No_UniColl & 1 \\
\hline
\end{tabular}

